\title{
LARVAL DEVELOPMENT OF THE INDONESIAN BLUE SWIMMING CRAB, PORTUNUS PELAGICUS (L) (CRUSTACEA : DECAPODA : PORTUNIDAE) REARED IN THE LABORATORY
}

by

\author{
SRI JUWANA ${ }^{1)}$ INDRA ASWANDY $^{1)}$ and M.G. LILY PANGGABEAN ${ }^{1)}$
}

\begin{abstract}
ABSTRAK
Sebanyak 137.870 ekor burayak rajungan, Portunus pelagicus (L) yang baru menetas dipelihara dalam wadah yang berkapasitas seribu liter. Burayak tersebut diberi makanan yang terdiri dari campuran Brachionus plicatilis dan nauplius Artemia salina yang baru menetas. Dalam percobaan ini dihasilkan 277 megalopa. Faktor lingkungan seperti temperatur, salinitas, pH dan DO dicatat. Pengaruh berbagai macam makanan yang digunakan oleh para penulis terdahulu dibandingkan dan dibahas. Masing-masing tingkat zoea dan megalopa digambar secara terperinci dan dipertelakan dengan mengutamakan jumlah dan tipe seta pada masing-masing umbai. Pola kromatofora pada tingkat zoea digambar dan dipertelakan.
\end{abstract}

\section{ABSTRACT}

A number of 137,870 freshly hatched larvae of Portunus pelagicus (L) were reared in one thousand litre container. The combination of Brachionus plicatilis and newly hatched nauplii of Artemia salina were fed to the larvae. The number of megalopa obtained was only 277. Ecological factor such as temperature, salinity, $\mathrm{pH}$ and dissolved oxygen were recorded. The effect of different food sources of the previous authors are compared. The detail description of the four zoeal stages and one megalopal stage are made and figured with emphasis on the number and type of setae on each appendages. A pattern of zoeal chromatophores is also sketched and described.

\section{INTRODUCTION}

The blue swimming crab,Portunus pelagicus (L), is known in Jakarta as Rajungan, constitutes an important crab fishery along the coastal area of Jakarta Bay (DELSMAN \& DE MAN, 1925). The meat of this crab is relished as a delicacy, therefore, the resources of the crab are exhaustively exploited everyday. It is feared that the intensive and indiscriminate fishing for this crab, and the absence of sufficient control management of net mesh size, will cause a decline in the crab population in the future. Investigations have therefore been initiated in the Centre for Oceanological Research and

1) Centre for Oceanological Research and Development-LIPI, P.O. Box 580 DAK, Jakarta, Indonesia. 
JUWANA, ASWANDY \& PANGGABEAN

Development-LIPI, Jakarta, Indonesia on the aspect of its biology (ROMIMOHTARTO 1979) and the possibility of its culture in a laboratory scale from the stage of the berried female (PANGGABEAN et al. 1982). Rearing experiments on this crab were initiated with the aim of deriving a mass culturing method by which the zoeae hatched by berried females could be reared into postlarval stages. However, the recent study showed that from 388,000 zoeal larvae which mainly fed with Brachionus plicatilis produced only 50 megalopae (PANGGABEAN et al 1982). To obtain higher survival of the megalopal stage, the present study tries to improve the feed by adding newly hatched nauplii of Artemia salina to the larvae. The major objectives of the study are : (1) to find a suitable food for rearing crab larvae; (2) to give detail description of each larvae with emphasis on the number and type of setae on each appendage.

\section{MATERIALS AND METHODS}

Ovigerous females were collected by bottom gill-nets from Jakarta Bay and transported in aerated sea water to the laboratory. To eliminate the contamination that might cause larval diseases they were treated with $50 \mathrm{ppm}$ formaldehyde. Afterwards each of the females was reared in aquaria containing 200 litre continuously aerated and regularly filtered sea water. The crabs were fed with pieces of fish or mollusc until hatching.

Hatching always occurs early in the morning. The number of hatched larvae from one female was approximately 137,870. Subsequently, the larvae were removed into a thousand litre conical bottom container. The ratio rotifer/larva of 10 was given in the first day. Afterwards, starting from the second day, the larvae were fed on a combination of 10 Brachionus plicatilis and 10 newly hatched nauplii of Artemia salina per larva. The rotifer diet consisted of dense cultures of the green algae, Tetraselmis chuii, which was cultured in medium EDTA(urea 100 ppm, K2HPO4 10 ppm, $\mathrm{FeCl}_{3} 2$ ppm and EDTA 2 ppm). A half volume of the sea water was changed daily and the ecological factors were recorded.

The larvae were sampled twice daily and preserved in $70 \%$ alcohol for examination. Dissection was done in $10 \%$ glycerin under a stereoscopic binocular microscope. Drawing of the larvae and their appendages were made by using projectina. Chromatophore pattern was sketched from the fresh and preserved zoeae. Measurements of the zoeae and megalopa were illustrated as Figure 1 and Figure 2. The classification of setal types follows BOOKHOUT \& COSTLOW (1974) for Portunus spinicarpus. It was possible to recognize eight different types of setae on the four zoeal and one megalopal stages of Portunus pelagicus larvae (Fig. 3). 


\section{LARVAL DEVELOPMENT OF THE INDONESIAN BLUE CRAB}

\section{RESULTS AND DISCUSSION}

\section{THE PRODUCTION OF THE MEGALOPA}

There are four zoeal stages and one megalopal stage in the complete larval development of Portunus pelagicus. Molting in the first to fourth zoea occurred regularly in two days interval. Then, the fourth zoea developed into megalopa within four days. The experiment produced 277 megalopae from 137,870 zoeal larvae. The ecological factors were recorded as follows: temperature ranged from $25^{\circ} \mathrm{Cto} 30^{\circ} \mathrm{C}$, salinity from $26 \%$ o to $29 \%$ o ,pH from 5.7 to 8.2 and dissolved oxygen from 5.3 ppm to 7.2 ppm.

YATSUZUKA \& SAKAI (1980) reported that the first up to the third zoea molted regularly with peak in three days respectively. The third zoea developed to the fourth zoea and then into the megalopa within three to four days. The zoeal larvae fed on newly hatched nauplii of Artemia salina. The temperature was $25^{\circ} \mathrm{C}$ to $27^{\circ} \mathrm{C}$ and gave no report on the survival percentage.

PANGGABEAN et al (1982) observed that the development of the crab larvae which fed on Brachionus plicatilis was as follows : molting in the first to fourth zoea occurred regularly with two days interval. The fourth zoea developed to megalopa within six days. The ecological factor were recorded as follows : temperature $25^{\circ} \mathrm{C}-$ $30^{\circ} \mathrm{C}$, salinity 26\%o - 28\%o , pH 5.7 - 8.2 and dissolved oxygen 5.3 ppm - 7.2 ppm

From the three experiments above, it can be perceived that molting from the first to the third zoea is faster on the rotifer diet than on the diet of the newly hatched nauplii of Artemia salina. In the other hand, molting to the fourth zoea takes longer on the rotifer diet than on the diet of newly hatched nauplii of Artemia salina. According to SULKIN \& EPIFANIO (1975) one of the criteria for a sufficient prey organism in the culture of early stage blue crab larvae is a size of not more than $0.110 \mathrm{~mm}$. The rotifers, Brachionus plicatilis, range in size between $0.45 \mathrm{~mm}$ to $0.180 \mathrm{~mm}$ in length; while the newly hatched nauplii of Artemia salina is found to measure $0.250 \mathrm{~mm}$ $0.300 \mathrm{~mm}$ in length. It seems that rotifers provide a good diet for rearing the first to the third zoeal stages of Portunus pelagicus, after which the nauplii of Artemia salina can be added to the feed. This diet shows better results.

In the present study, although the production of the megalopa is higher than that of the previous studies (PANGGABEAN et al. 1982), the result is insufficient for standard of seedlings production. WATANABE et al. (1983) find that highly unsaturated fatty acids such as 20 : $5 \mathrm{~W} 3$ and $20: 6 \mathrm{~W} 3$ which are contained in the nauplii of Artemia salina are very effective for seed production of marine fish. In the present study, the combination of Brachionus plicatilis and Artemia salina as feed can fulfil the need of the specificity of highly unsaturated fatty acid and give a better result than that using Brachionus plicatilis only. It is also considered that the megalopa tends to stay on the bottom of the container rather than swim near the surface. In order to increase the production of the megalopa, the planktonic organisms can not be recommended as the main food. JuWANA (1984) observes that the morphology of the feeding apparatus 


\section{JUWANA, ASWANDY \&PANGGABEAN}

of the megalopa of Portunus pelagicus is well developed. Therefore, it is suggested that solid-sinked foods such as minced fish, clams or molluscs be added for rearing the megalopa. It is also considered that since the density of the larvae in the present study $(137,870$ larvae per one thousand litre of water) is less than that in the previous study (388,000 - 514,000 larvae per one thousand litre of water), this condition may produce higher yield of the megalopa stage.

\section{DESCRIPTION OF THE LARVAE}

According to LEBOUR (1928) the following characters are the most important in identifying crab larvae : (1) number of zoeal stages, (2) presence or absence of spines on the carapace, (3) character of antennae, (4) character of the armature of telson and (5) character of the armature of the abdominal segments. The present study describes the complete larval development of Portunus pelagicus with emphasises on the setation of all appendages and zoeal chromatophores pattern. The main morphological characters of each larval stage are compared with the larval development of Portunus pelagicus from Japan (YATSUZUKA \& SAKAi, 1980) and Australia (SHINKARENKO 1979), in order to note some differences on the setation of the appendages.

\subsection{First zoea}

Cephalothorax is covered by carapace which has dorsal, rostral and lateral spines. Carapace length $0.48 \mathrm{~mm}$; rostral and lateral spines measure $0.60 \mathrm{~mm}, 0.47 \mathrm{~mm}$ and 0.11 $\mathrm{mm}$ respectively (Fig. 4a, b, Table 1). Eyes are not stalked. Abdomen consists of five segments plus a telson. Second segment with a knob-like projection situated medio-laterally. Third to fifth segments with postero lateral projections (0.04 - $0.06 \mathrm{~mm}$, Fig. 4c). Third segment bears a small hook-like projection situated medio-laterally on each side. Each furca of the telson bears small dorsal and lateral spines. Three serrate spines present on the inner margin of each furca, inner spine having six stiff setules situated approximately on the middle of its inner margin (Fig. 4c).

Antennule conical, with three aesthetasc setae situated terminally (Fig. 4d, Table 2).

Antenna consists of one elongated protopodite $(0.23 \mathrm{~mm})$ bearing two rows of minute spines on its distal half, one exopodite bearing long and short terminal spines (Table 2, Fig. 4e).

Mandibles asymmetrical, consist of incisor and molar as shown in Figure 4f.

Setation on coxal and basal endites of maxillule are listed in Table 3 (Fig. 4g). Endopodite two-segmented; distal segment with four terminal and two subterminal plumodenticulate setae, basal segment with one plumodenticulate lateral seta.

Setation of proximal and distal lobes of coxal and basal endites of maxilla are listed in Table 4. Endopodite bears four long terminal plumodenticulate setae and two long subterminal plumodenticulate setae. Scaphognathite bears four plumose setae on its anterior and lateral margin and one long stout posterior plumose setae (Fig. 4h). 
LARVAL DEVELOPMENT OF THE INDONESIAN BLUE CRAB

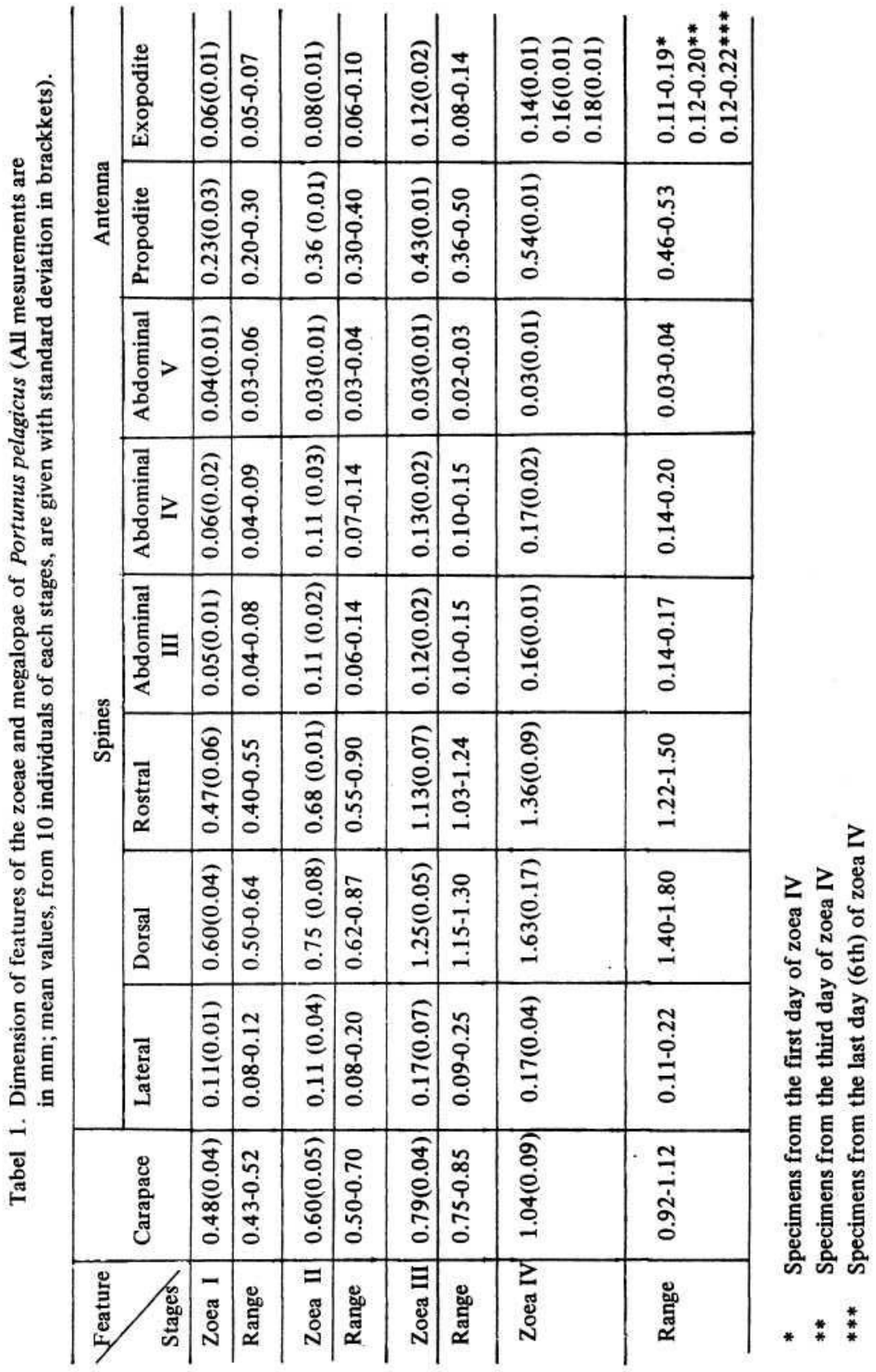


JUWANA, ASWANDY \&PANGGABEAN

Tabel 2. Setation of antennules of Portunus pelagicus.

\begin{tabular}{l|l|l|l|l}
\hline Stages & $\begin{array}{l}\text { Position of } \\
\text { setae }\end{array}$ & $\begin{array}{c}\text { Present } \\
\text { authors }\end{array}$ & $\begin{array}{c}\text { SHINKARENKO } \\
(1979)\end{array}$ & $\begin{array}{c}\text { YATSUZUKA \& } \\
\text { SAKAI (1980) }\end{array}$ \\
\hline Zoea I & $\begin{array}{l}\text { Terminal } \\
\text { Sub terminal }\end{array}$ & $\begin{array}{c}3 \mathrm{a} \\
-\end{array}$ & $\begin{array}{c}2 \mathrm{a}+1 \mathrm{~s} \\
-\end{array}$ & $\begin{array}{l}3 \mathrm{a} \\
-\end{array}$ \\
\hline Zoea II & $\begin{array}{l}\text { Terminal } \\
\text { Sub terminal }\end{array}$ & $\begin{array}{c}5 \mathrm{a} \\
-\end{array}$ & $\begin{array}{l}7 \mathrm{a}+2 \mathrm{~s} \\
-\end{array}$ & $5 \mathrm{a}$ \\
\hline Zoea III & Terminal & $4 \mathrm{a}$ & $5 \mathrm{a}+2 \mathrm{~s}$ & $6 \mathrm{a}$ \\
& Sub terminal & $3 \mathrm{a}$ & $1 \mathrm{a}$ & $2 \mathrm{a}$ \\
\hline Zoea IV & Terminal & $5 \mathrm{a}$ & $5 \mathrm{a}+2 \mathrm{~s}$ & $5 \mathrm{a}$ \\
& Sub terminal & $5 \mathrm{a}$ & $4 \mathrm{a}$ & $(4+1) \mathrm{a}$ \\
\hline Megalopa & 2nd segment & $5 \mathrm{a}^{*}$ & $10 \mathrm{a}$ & $7 \mathrm{a}$ \\
(outer anten- & 3rd segment & $5 \mathrm{a} *$ & $10 \mathrm{a}$ & $6 \mathrm{a}$ \\
nular ramus) & 4th segment & $4 \mathrm{a}^{*}$ & $6 \mathrm{a}$ & $4 \mathrm{a}$ \\
\hline
\end{tabular}

* Specimens from the first day of megalopa stage,

$\mathbf{a}=$ Aesthetasc seta

$\mathrm{s}=$ simple seta

Exopodite of first maxilliped bears four natatory plumose setae and the five segmented endopodite has setation from base to tip of 2, 2,0, 2, 5 (Fig. 4i).

Exopodite of second maxilliped bears four natatory plumose setae and the threesegmented endopodite has a serrate setae on its basal and middle segments and five setae on the terminal segment. The latter includes one long serrate, one long plumose and three simple setae (Fig. $4 \mathrm{j}$ ).

Third maxilliped has not yet developed.

\subsection{Second zoea}

The general morphology of cephalothorax and abdomen are essentially the same as in the first zoea (Fig. 5a), except a pair of short hair like projections has been added to the central arch of telson (Fig. 5c), and eyes have become stalked (Fig. 5b).

Antennule has five terminal aesthetasc setae (Table 2; Fig. 5d).

Protopodite of antenna, from the point of branching, has grown from $0.23 \mathrm{~mm}$ to $0.36 \mathrm{~mm}$, where as exopodite has grown from $0.06 \mathrm{~mm}$ to $0.08 \mathrm{~mm}$. The bud of endopodite appears at the base of endopodite (Table 1; Fig. 5e).

Mandibles do not show perceptible change (Fig. 5f).

Setation of coxal and basal endites of maxillule increases in the number of setae as shown in Table 3. Setation of endopodite is the same as in the first zoea. A long plumose seta is situated on the outer margin of the fused base-coxopodite (Fig. 5g). 
LARVAL DEVELOPMENT OF THE INDONESIAN BLUE CRAB

Table 3. Setation of maxillule of larval stages of Portunus pelagicus

\begin{tabular}{|c|c|c|c|c|c|}
\hline \multirow{3}{*}{ Stages } & \multirow{2}{*}{\multicolumn{2}{|c|}{$\begin{array}{r}\text { Present authors } \\
\text { Coxal endite }\end{array}$}} & \multirow{3}{*}{$\begin{array}{l}\text { SHINKARENKO (1979) } \\
\text { Coxal endite }\end{array}$} & \multirow{2}{*}{\multicolumn{2}{|c|}{$\frac{\text { YATSUZUKA \& SAKAI }(1980)}{\text { Coxal endite }}$}} \\
\hline & & & & & \\
\hline & Terminal & Subterminal & & Terminal & Subterminal \\
\hline Zoea I & $5 \mathrm{gmd}$ & $1 p+1 s$ & $7 \mathrm{gmd}$ & 5 setae & $(1+1)$ setae \\
\hline Zoea Il & $6 \mathrm{gmd}$ & & $7 \mathrm{gmd}$ & 6 setae & 1 seta \\
\hline Zoe III & $6 \mathrm{gmd}$ & $2 p+1 s$ & $9 \mathrm{gmd}$ & 5 setae & $(1+1)$ setae \\
\hline Zoea IV & $6 \mathrm{gmd}$ & $2 p+1 s$ & $9 \mathrm{gmd}$ & 10 setae & 3 setae \\
\hline \multirow[t]{3}{*}{ Megalopa } & $8 \mathrm{gmd}$ & $7 \mathrm{gmd}$ & $4 c+2 g m d+3 p+9 p$ & 18 setae & \\
\hline & \multicolumn{2}{|c|}{ Basal endite } & \multirow[t]{2}{*}{ Basal endite } & \multicolumn{2}{|c|}{ Basal endite } \\
\hline & Terminal & Subterminal & & Terminal & Subterminal \\
\hline Zoea I & $3 c+2 p d$ & - & $2 c+3 p d$ & 5 setae & \\
\hline Zoea 11 & $4 c+4 p d$ & 1s & $4 c+5 p d$ & 8 setae & 1 seta \\
\hline Zoea III & $4 c+4 p d$ & $2 \mathrm{pd}$ & $4 c+6 p d$ & 8 setae & 2 setae \\
\hline Zoea IV & $6 c+5 p d$ & $2 \mathrm{pd}$ & $5 c+5 p d$ & 7 setae & 3 setae \\
\hline \multirow[t]{2}{*}{ Megalopa } & $7 c+7 g m d$ & $5 p$ & $12-13 c+12-13 p d$ & 24 setae & \\
\hline & \multicolumn{2}{|c|}{ Outer setae } & Outer setae & \multicolumn{2}{|l|}{ Outer setae } \\
\hline Zoea I & \multicolumn{2}{|l|}{$1 \mathrm{p}$} & - & \multicolumn{2}{|l|}{-} \\
\hline Zoea II & \multicolumn{2}{|l|}{$2 \mathrm{p}$} & $2 p$ & \multicolumn{2}{|l|}{1 seta } \\
\hline Zoea III & \multicolumn{2}{|l|}{$2 \mathrm{p}$} & $2 \mathrm{p}$ & \multicolumn{2}{|l|}{2 setae } \\
\hline Zoea IV & \multicolumn{2}{|l|}{$2 \mathrm{p}$} & $2 \mathrm{p}$ & \multicolumn{2}{|l|}{2 setae } \\
\hline
\end{tabular}

$\mathrm{c}=$ cuspidate seta; gmd = grade multi denticulate seta; $\mathrm{p} \quad$ plumose seta; $\mathrm{pd}=$ plumodenticulate seta;

$\mathrm{s}=$ simple seta 


\section{JUWANA, ASWANDY \&PANGGABEAN}

Setation of proximal and distal lobes of coxal and basal endites of maxilla is given in Table 4 (Fig. 5h). Setation of endopodite is the same as in the first zoea. Scaphognathite has five lateral plumose setae on its anterior position and three lateral setae on its posterior position.

First and second maxillipeds have exopodites with six or eight natatory plumose setae; setation of endopodite unchanged (Fig. 5i,j). Buds of third maxillipeds and leg buds are present under carapace (Fig. 5a).

Table 4. Setation of maxilla of the larval stages of Portunus pelagicus

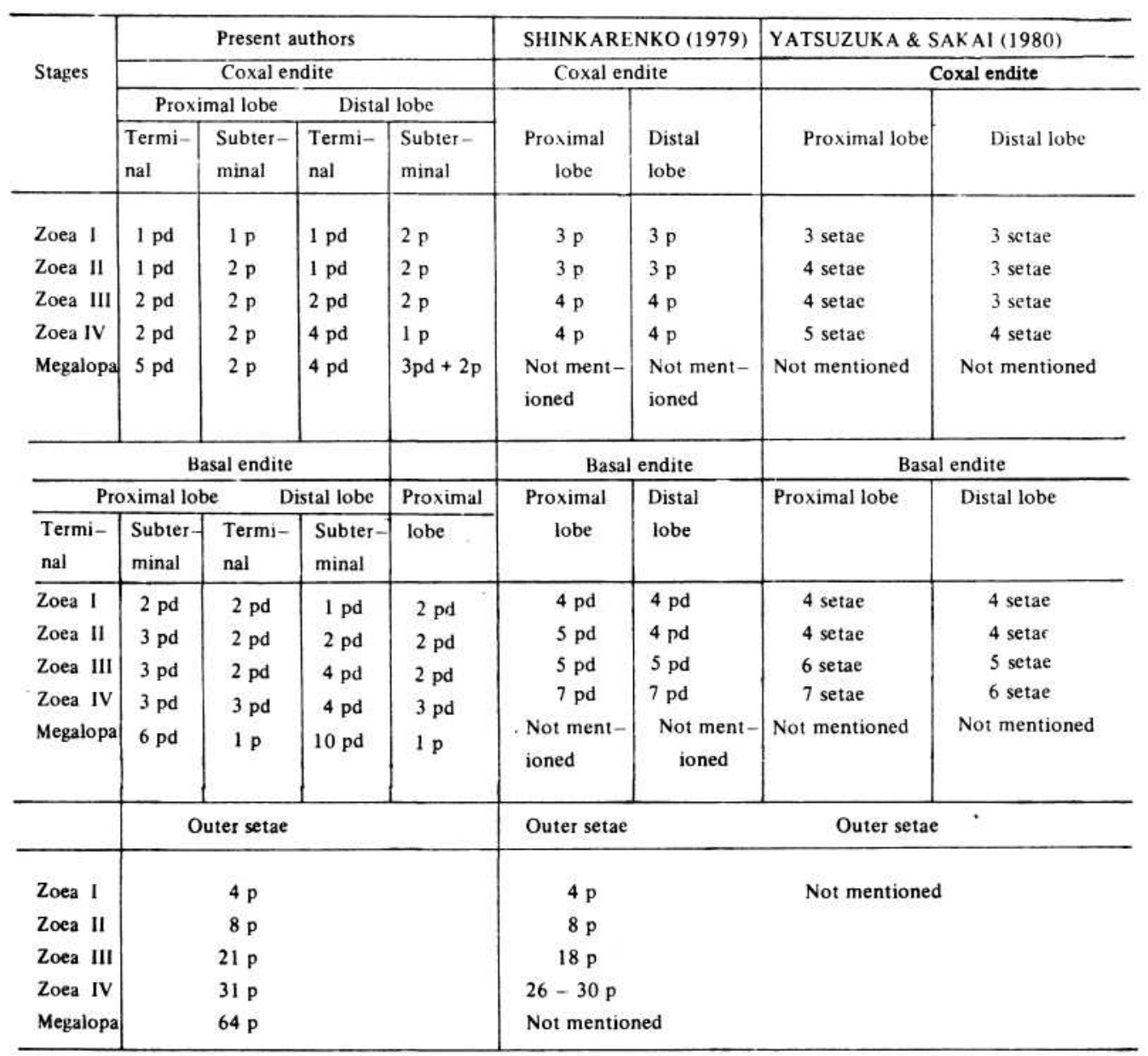

$\mathrm{p}=$ plumose seta,$\quad \mathrm{pd}=$ plumodenticulate seta 


\section{LARVAL DEVELOPMENT OF THE INDONESIAN BLUE CRAB}

Table 5. Dimension of various features of the megalopa of Portunus pelagicus (All measurements are in mm; mean values, from 10 individuals of each stage, are given with standard deviation in brackets).

\begin{tabular}{l|l|l}
\hline Feature & Mean and SD & Range \\
\hline Total length & $1.94(0.141)$ & $1.90-2.00$ \\
Rostrum length & $0.374(0.050)$ & $0.35-0.40$ \\
Carapace width & $1.13(0.056)$ & $1.00-1.20$ \\
\hline
\end{tabular}

\subsection{Third zoea}

Rostral spine lengthened from $0.68 \mathrm{~mm}$ to $1.13 \mathrm{~mm}$ and dorsal spine, from 0.75 $\mathrm{mm}$ to $1.25 \mathrm{~mm}$ (Table 1; Fig. 6a,b).

Sixth abdominal segment appears, but it lacks spines (Fig. 6c).

Antennule setation is given in Table 2. A small bud of the inner ramus appears for the first time (Fig. 6d).

Setation of antenna is the same as in the previous stage. Bud of endopodite lengthened to almost reaching tip of exopodite (Fig. 6e).

The incisor portion of the mandible more developed than that of molar (Fig. 6f).

Setation of coxal endite and basal endite of maxillule is given in Table 3 (Fig. 6g). Setation of endopodite remains unchanged. Two long plumose setae present on the outer margin of the fused baso-coxopodite.

Setation of proximal and distal lobes of coxal and basal endites of maxilla is given in Table 4 (Fig. 6h). Endopodite unchanged. Scaphognathite has 21 to 26 marginal plumose setae.

Endopodite of first maxilliped has the same setation as in the second zoea; now, setation of endopod of second maxilliped is 2, 2, 0, 2, 6 and each of exopodite has 10 natatory plumose setae (Fig. 6i). Buds of third maxillipeds and pereiopod are longer than the second zoea. Pleopod buds appear for the first time on second to six abdominal segments (Fig. 6a).

\subsection{Fourth zoea}

Rostral and dorsal spines increase in length from third to fourth zoeal stage, from $1.13 \mathrm{~mm}$ to $1.36 \mathrm{~mm}$ and from $1.25 \mathrm{~mm}$ to $1.63 \mathrm{~mm}$ respectively (Table 1 ; Fig. 7a, b). A minute hair appears in the middle arch of telson (Fig. 7c).

Antennule setation is given in Table 2 (Fig. 7d).

Setation of antenna is the same as in the previous stage; endopodite is now longer than exopodite, which varies in length from about the same length of exopodite plus long spine to about the middle of spined protopodite (Fig. 7e).

Mandible with a bud of mandibular palp which is situated behind the corpus of mandibulae. Molar portion with two teeth (Fig. 7f).

Setation of coxal and basal endites of maxillule is given in Table 3. Endopodite remains unchanged, two long plumose setae present on the outer margin on the fused baso-coxopodite (Fig. 7g). 


\section{JUWANA, ASWANDY \&PANGGABEAN}

Setation of proximal and distal lobes of coxaland basal endites of maxilla is given in Table 4(Fig. 7h). Endopodite remains unchanged. Scaphognathite bears 31 plumose setae along its border.

Exopodite of first and second maxillipeds have 12 to 14 natatory plumose setae. Setation of endopodite of first maxillj.ped is 2, 2, 1, 2, 6 (Fig. 7i). Setation of endopodite of second maxilliped is the same as described in the previous stage (Fig. 7j).

Pereiopod buds are longer than in the previous stage; first pereiopod is chelate and segmented (Fig. 7a).

Pleopods are well developed and biramous on second to.fifth abdominal segments; those on the sixth segment are not biramous (Fig. 7a,c).

\subsection{Chromatophore pattern on the zoeal stages}

The pattern of chromatophores is fairly consistent throughout zoeal development. They are diagramed and numbered in Figure 8, Black and brown chromatophores can be observed on up to three-month preserved larvae. Reddish-orange chromatophores can only be examined on fresh larvae or maximum on one-week preserved larvae. The description of the chromatophore pattern on the zoeal stages is as follows : Black dispersed chromatophores can be seen on rostral base of some first zoeal stage specimens (1). This chromatophore remains for only about one week on the preserved specimens. A path of black chromatophores is situated on mid dorsal of carapace (3), on the basal of spina dorsalis (4) and on the labrum (11). Brown chromatophores are seen on the anterior margin of carapace (2), over the midgut (7), on the posterior of lateral spine (8), on the coxopodite of the first maxilliped (9), on the mandible (10), on the distal region of basipodite of first maxilliped (12), on the dactylus of first pereiopod (13). over the intestine of first abdominal segment $(14 \& 15)$ and on the ventro-posterior of third to sixth abdominal segment (16 - 19). A patch of reddish-orange chromatophore is on the half way up from base of the dorsal spine, in the first zoea which is gradually extends along the dorsal spine (5); and on the anterior of the lateral spine which extends to dorsal and ventral directions in the later stages (6). Reddish-orange chromatophores are situated over the intestine (14a), at lateral side of the second abdominal segment (15 a) and on the ventro-posterior of third to sixth abdominial segment (16a-19a).

\subsection{Megalopa}

Carapace is rectangular, without dorsal or lateral spines (Table 5; Fig. 9a) and with an anteriorly directed pointed rostrum, which is about a half the length of antennae. A pair of spines extend from the fourth sternal segment posteriorly beyond the base of the fifth legs (Fig. 9b). Telson uniramous, rounded, dorsoventrally flattened and bears numerous simple setae on its posterior margin.

Antennule (Fig. 10a) consists of the three-segmented penduncle, unsegmented endopod and five-segmented exopod. Basal segment of penduncle bulbous; second segment elongated and bears distally plumose setae; third segment broadens and bears distally one very sparse plumose setae. Endopod bears three plumodenticulate setae 


\section{LARVAL DEVELOPMENT OF THE INDONESIAN BLUE CRAB}

terminally and two subterminally. Proximal segment of exopod has no setae; second and third segments, each has aesthetasc setae on outer margin; terminal segment has two stiff simple setae, one terminally and the other subterminally.

Antenna (Fig. 10b) uniramous and consists of eleven segments. Proximal segment is the longest, without setae; fourth segment is the shortest, fifth and seventh segments are also without setae, the other seven segments bear setae with variation as shown in Figure $10 \mathrm{~b}$.

Mandible (Fig. 10c) asymmetrical. The cutting edge of the left side smooth. There is two-segmented pulp with seven to eight plumodenticulate setae on the segment distalis.

Maxillule (Fig. 1Od) consists of segmented coxal endite, unsegmented basal endite and two-segmented endopod. Setation of coxal endite and basal endite is given in Table 3. Proximal segment of endopod has two plumose setae on inner margin and distal segment has two simple setae terminally.

Maxilla (Fig. 1Oe) consists of bilobed-coxal endite, bilobed-basal endite, twosegmented endopod and large unsegmented scaphognathite. Setation of coxal and basal endites is given in Table 4. Endopod reduced; proximal segment has three plumose setae and distal segment has no setae. Scaphognathite broad, brimmed with a number of plumose setae.

First maxilliped (Fig. lOf) consists of unsegmented coxopodite, unsegmented basipodite, unsegmented endopod, two-segmented basipodite, unsegmented endopod, two-segmented exopod and unsegmented epipod. Coxopodite bears nine marginal plumodenticulate setae, one plumodenticulate setae and two submarginal simple setae. Basipodite bears marginally 16 plumodenticulate setae and one plumose seta; it has also submarginally two plumodenticulate setae and three simple setae. Endopod bears distally four plumodenticulate setae and proximally two plumose setae. Distal segment of exopod bears terminally six plumose setae; proximal segment has no setae. Epipod has four long plumose setae.

Second maxilliped (Fig. $\mathrm{lOg}$ ) consists of four-segmented endopod, three-segmented exopod, unsegmented epipod and a small gill. Proximal segment of endopod elongated and has three distally and two proximally plumodenticulate setae; second segment has two; third segment has seven and distal segment has nine plumodenticulate setae. Proximal segment of exopod bears one simple seta on outer margin and distal segment has terminally four long plumose setae.

Third maxilliped (Fig. lOh) consists of five-segmented endopod, two segmented exopod, unsegmented epipod and gill. Proximal segment of endopod bears 18 plumodenticulate setae on inner margin, four on lateral margin and one on outer margin;

\section{ACKNOWLEDGEMENTS}

The authors wish to express their sincere gratitude to Dr. Aprilani Soegiarto, Project Manager of the Project on Research and Development of Marine Natural Resources, Indonesian Institute of Sciences, for supporting the research. Great acknow- 


\section{JUWANA, ASWANDY \&PANGGABEAN}

legements are due to Dr. Kasijan Rominiohtarto and Dr. M. Kasini Moosa for providing the authors with relevant references and for their continuous encouragement, valuable advices and comments. The authors would like to. thank Mr. Sulistijo for his valuable guidance and suggestions during the experiment. Thanks are also extended to Messrs. Herri Sugiarto, Rio Haryanto and Eko Maryono Budiono for their technical help in the rearing programme and typing the manuscript.

\section{REFERENCES}

BOOKHOUT, C.G. and J.D. COSTLOW 1974. Larval development of Portunus spinicarpus reared in the laboratory. Bull. Mar. Sci. 24 (1) : 20 - 51.

DELSMAN, H.C. and J.G. JDE MAN 1925. On the "Radjungans" of the bay of Batavia. Treubia 6 ( 3-4) : 308 -328. JUWANA, \& 1984. Morfologi alat-alat penangkap mangsa pada burayak rajungan (Portunus pelagicus). Oseanologi di Indonesia $17: 1-11$.

PANGGABEAN, M.G.L.; S. JUWANA and I. ASWANDY 1982. Pengamatan burayak rajungan (Portunus pelagicus) di Lembaga Oseanologi Nasional - LIPI. Oseanologi di Indonesia 15 : 37 - 50. ROMIMOHTARTO, K. 1979. Hasil penelitian pendahuluan tentang biologi budidaya rajungan, Portunus (Portunus) pelagicus (LINN.) dari Teluk Jakarta dan Pulau Pan (Pulau-Pulau Seribu). Laporan (Proceedings) Seminar V \& Kongres III Biologi Indonesia 1: 199 - 216.

SHINKARENKO, L 1979. Development of the larval stages of the blue swimming crab Portunus pelagicus L. (Portunidae : Decapoda : Crustacea). Aust. J. Freshwater Res. 30 : 485 503.

SULKIN, S.D. and C.E. EPIFANIO 1975. Comparison of rotifers and other diets for rearing early larvae of the blue crab, Callinectes sapidus RATHBUN. Est. Coast. Mar. Sci 3 : 109 113.

WATANABE, T.; C. KiTAJIMA and S. FUJITA 1983. Nutritional values of live organisms used in Japan for mass propagation offish : A Review. A quaculture 34 : $115-143$. YATSUZUKA,

K. and K. SAKAI 1980. The larvae and juvenile crabs check Japanese Portunidae (Crustacea, Brachyura). I. Portunus (Portunus) pelagicus (LINNE). USA. Mar. Biol Inst. $2: 25-41$. 


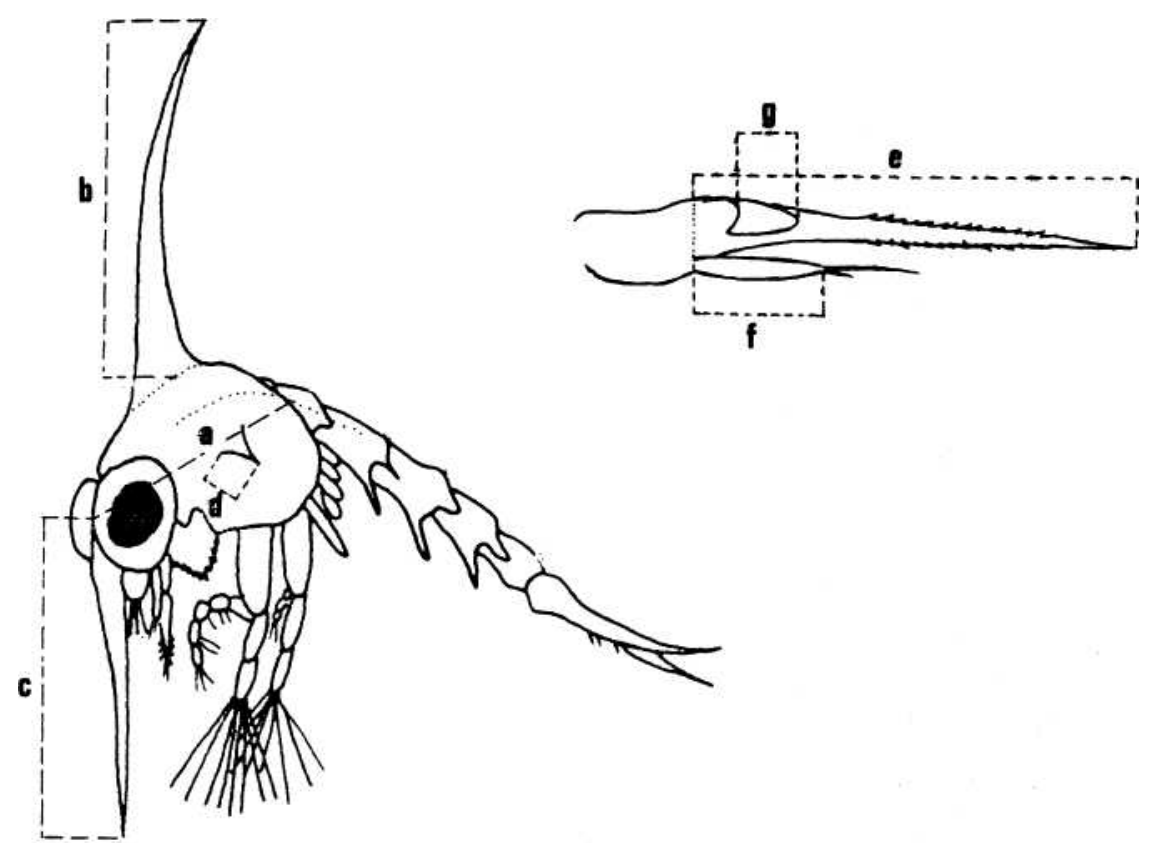

Figure 1. Zoeal larva showing limits for length measurements of carapace (a), dorsal spine (b), rostral spine (c), lateral spine (d), protopodite (e), exopodite (f) and endopodite (g).

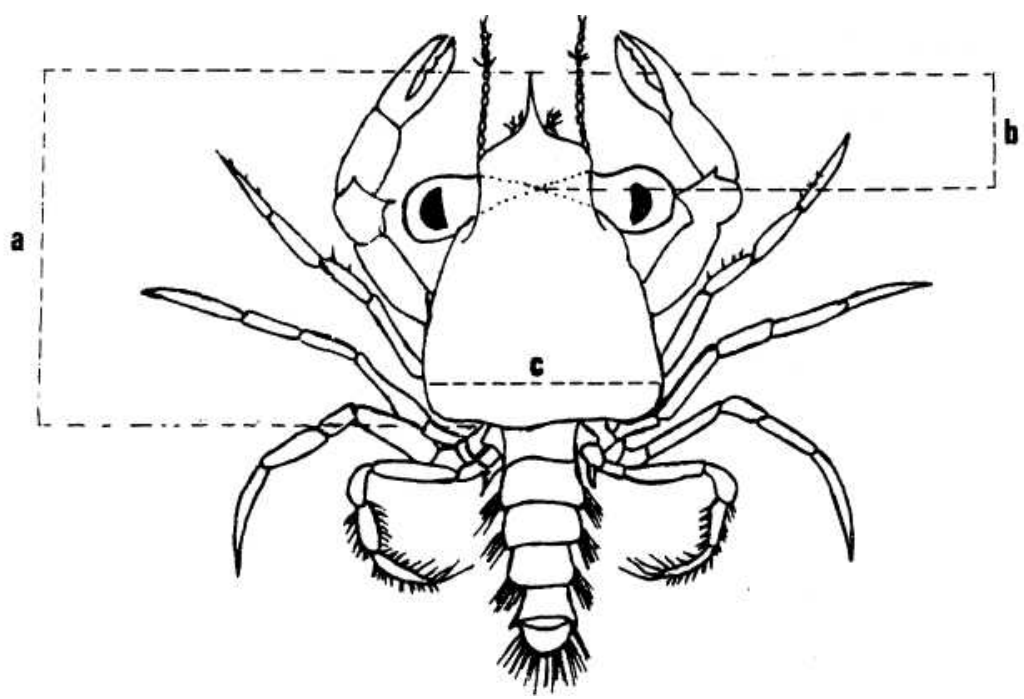

Figure 2. Megalopal larva showing limits for measurements of total length (a), rostrum length (b), and carapace width (c). 
JUWANA, ASWANDY \&PANGGABEAN
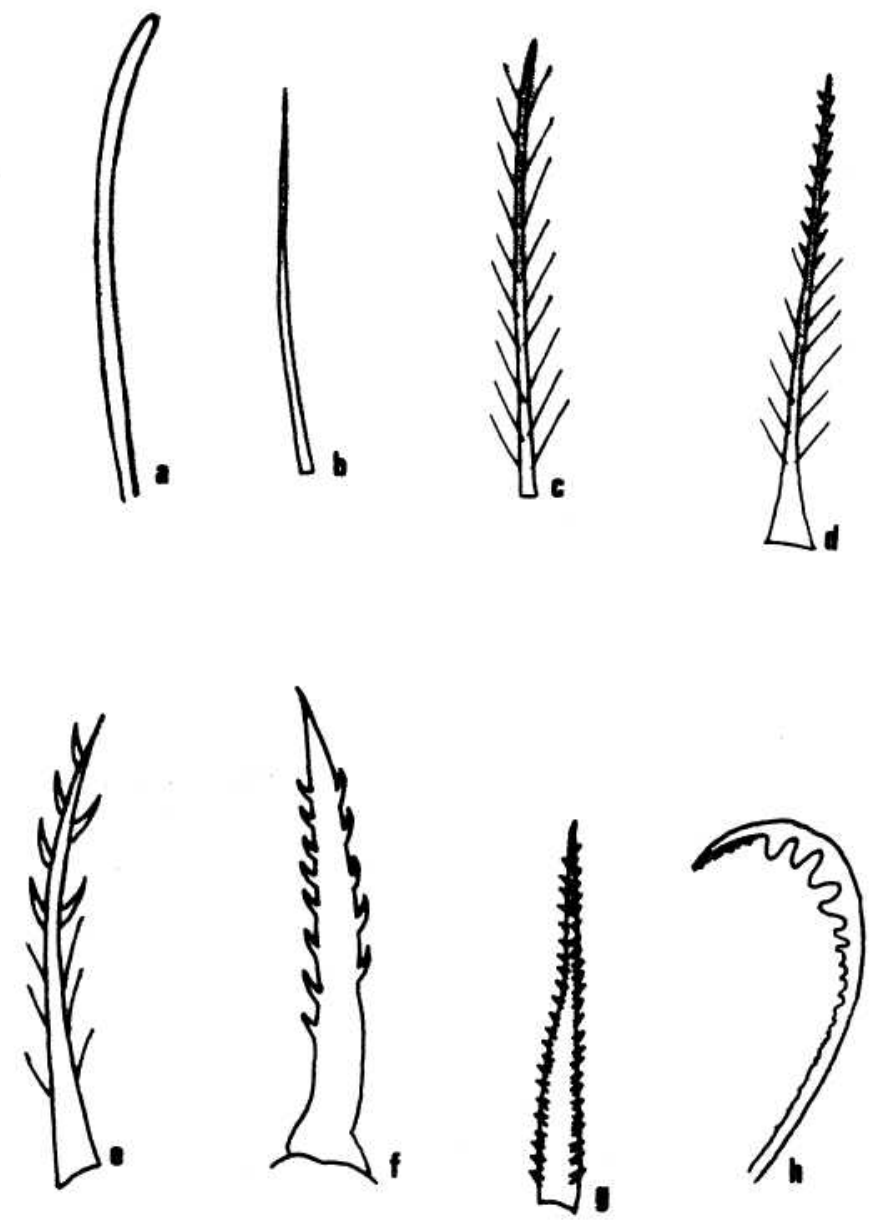

Figure 3. Setai types found on appendages of larvae of Portunus pelagicus : a, aesthetasc; b, simple; c, plumose; d, plumodenticulate; e, graded multidenticulate; f, cuspidate; g, serrate; h, modified serrate. 


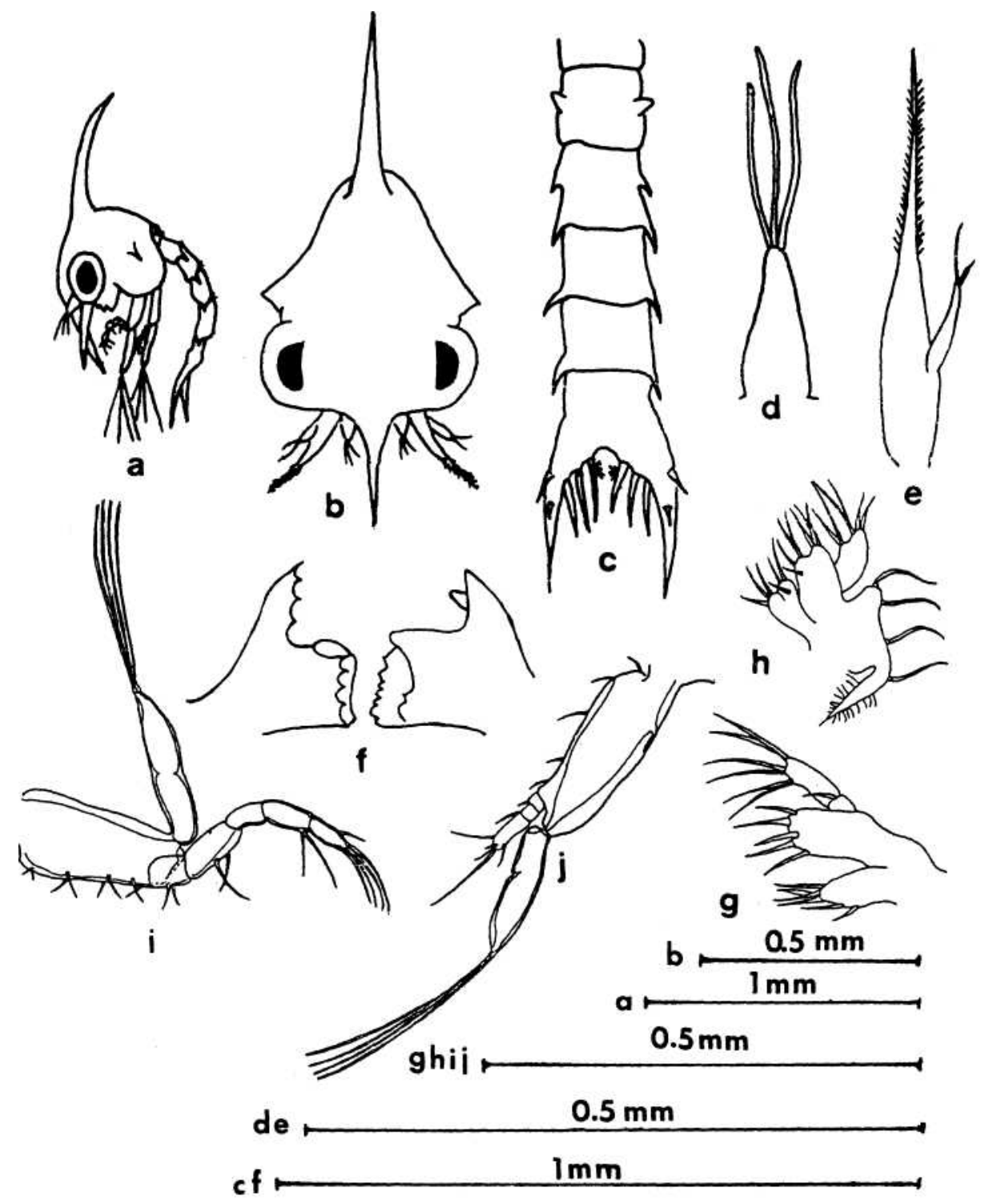

Figure 4. Zoea 1 of Portunus pelagicus: a, lateral view; b, frontal view of cephalothorax; c dorsal view of abdomen and telson; d, antennule; e, antenna; f, mandible; g, maxillule; h, maxilla; e, first maxilhped;j, second maxilliped 
JUWANA, ASWANDY \& PANGGABEAN

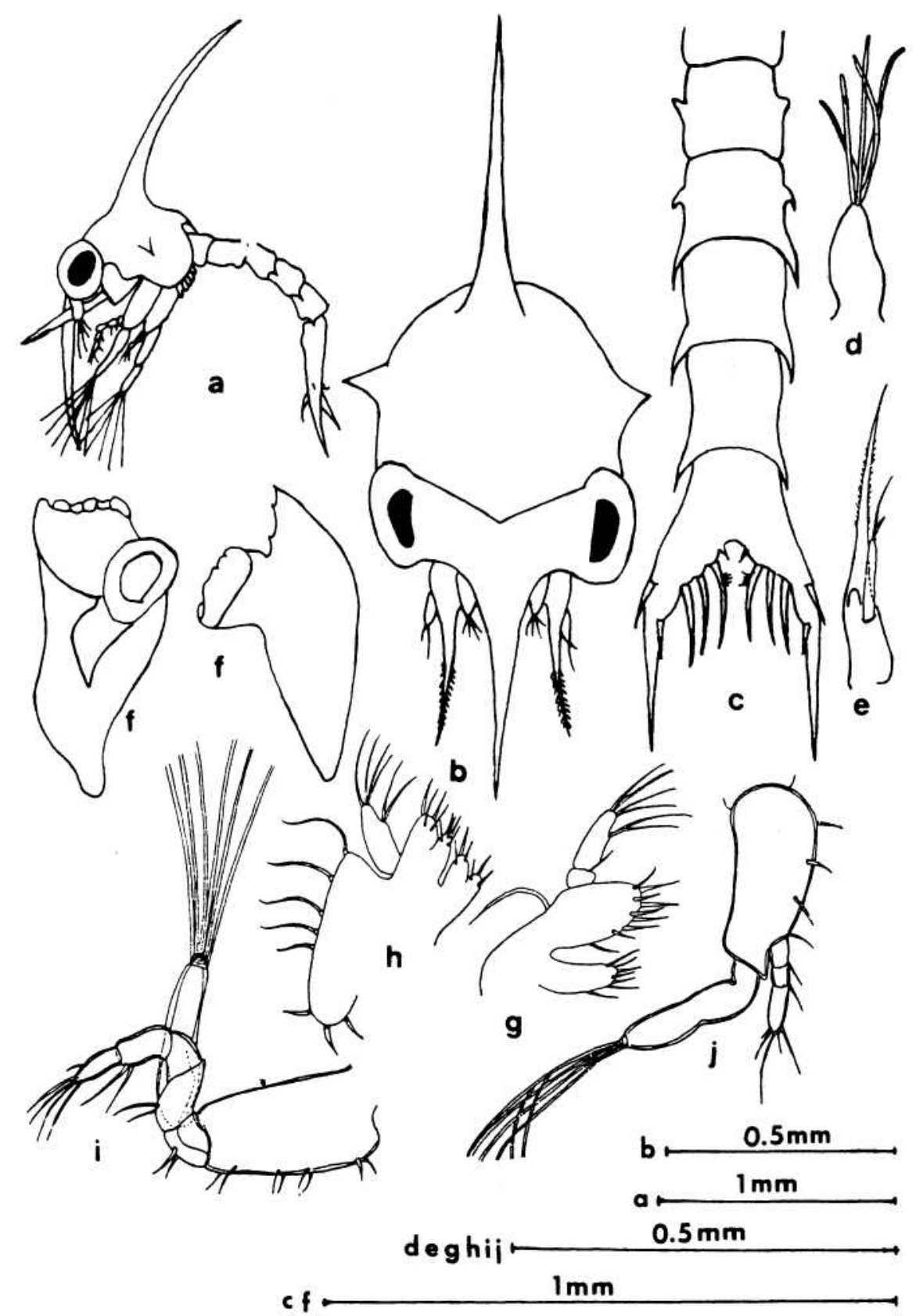

Figure 5. Zoea II of Portunus pelagicus: a, lateral view; b, frontal view of cephalothorax; c, dorsal view of abdomen and telson; d, antennule; e, antenna; f, mandible; g, maxillule; h, maxilla; i, first maxilliped; j, second maxilliped. 
LARVAL DEVELOPMENT OF THEINDONESIAN BLUE CRAB

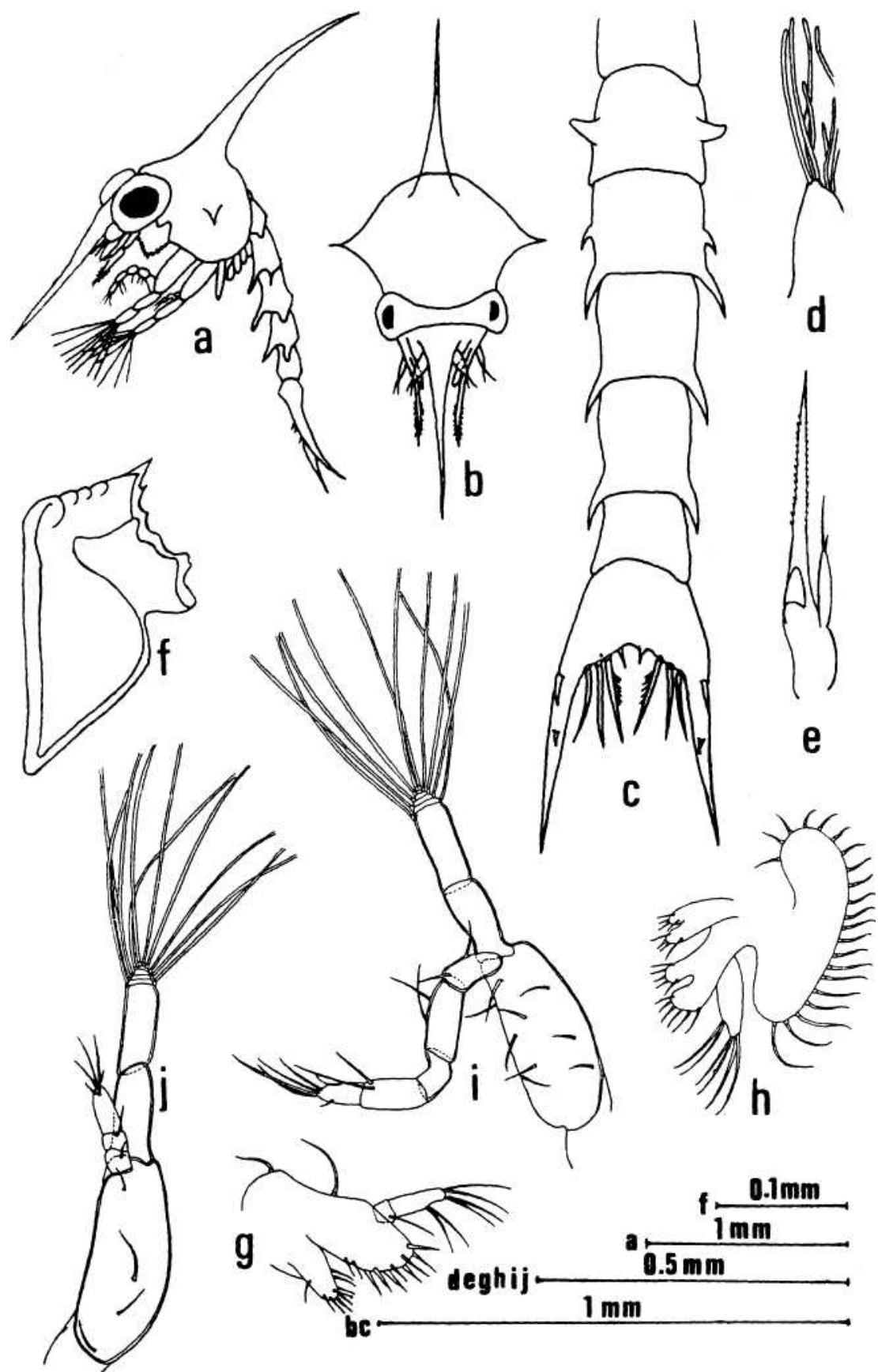

Figure 6. Zoea III of Portunus pelagicus: a, lateral view; b, frontal view of cephalothorax; c, dorsal view of abdomen and telson; d, antennule; e, antenna; f, mandible; g, maxillule; h, maxilla; i, first maxilliped; j, second maxilliped. 
JUWANA, ASWANDY \& PANGGABEAN

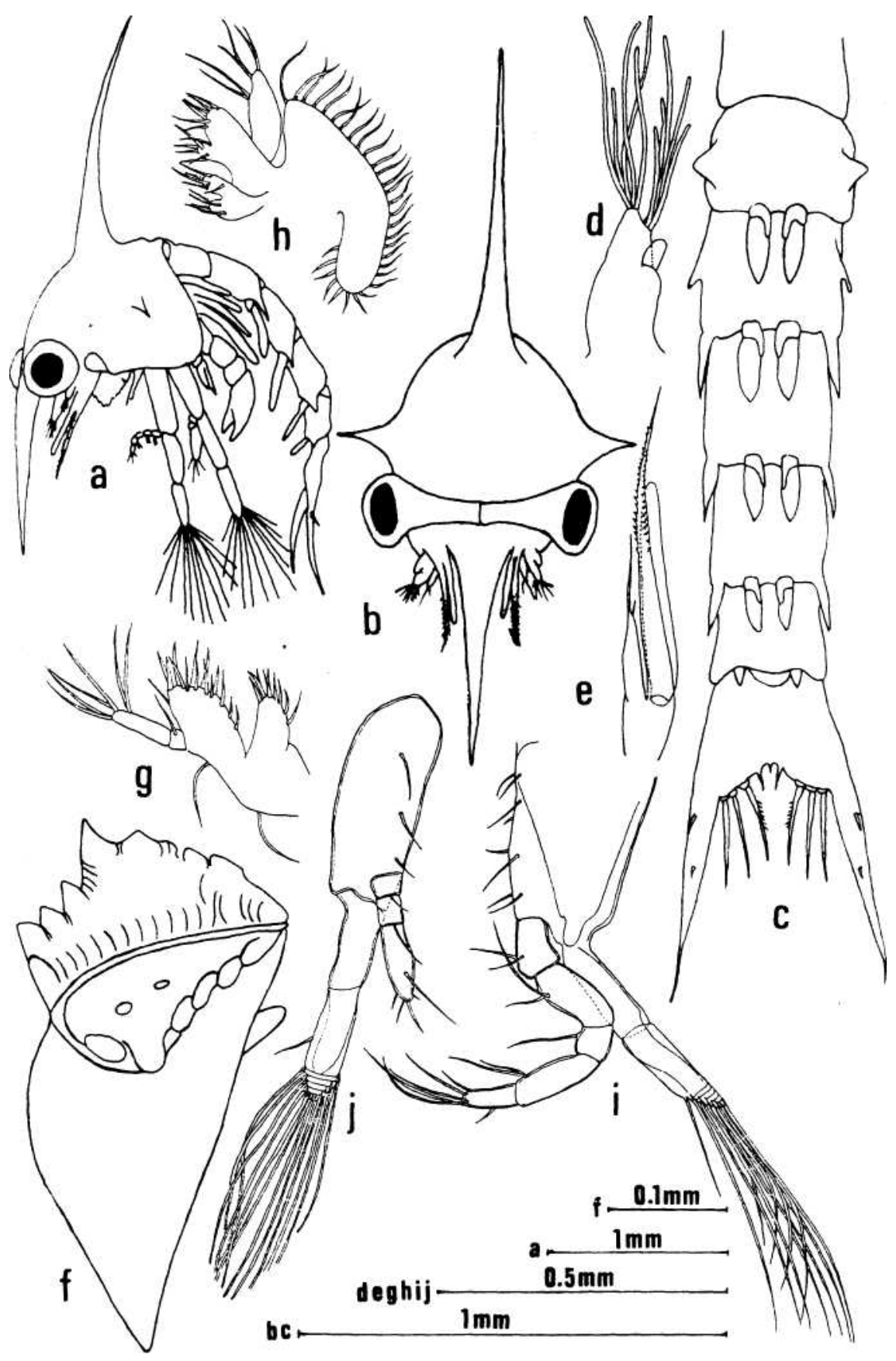

Figure 7. Zoea IV of Portunus pelagicus: a, lateral view; b, frontal view of cephalothorax; c, ventral view of abdomen and telson; d, antennule; e, antenna; f, mandible; g, maxillule; h, maxilla; i, first maxilliped; j, second maxilliped. 


\section{LARVAL DEVELOPMENT OF THE INDONESIAN BLUE CRAB}
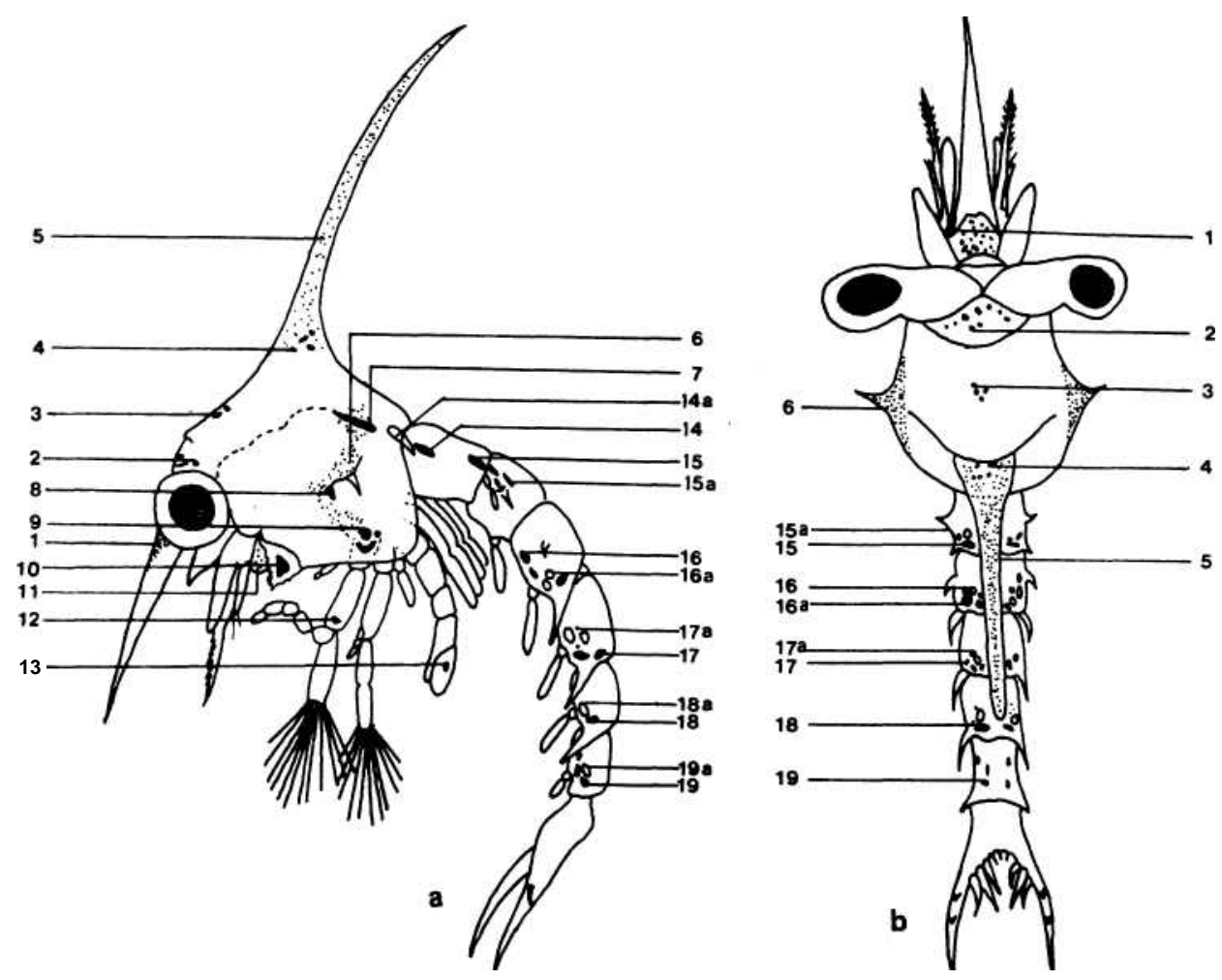

Figure 8. Pattern of chromatophores of zoea IV of Portunus pelagicus: a, lateral view; b, dorsal view 
JUWANA, ASWANDY \& PANGGABEAN
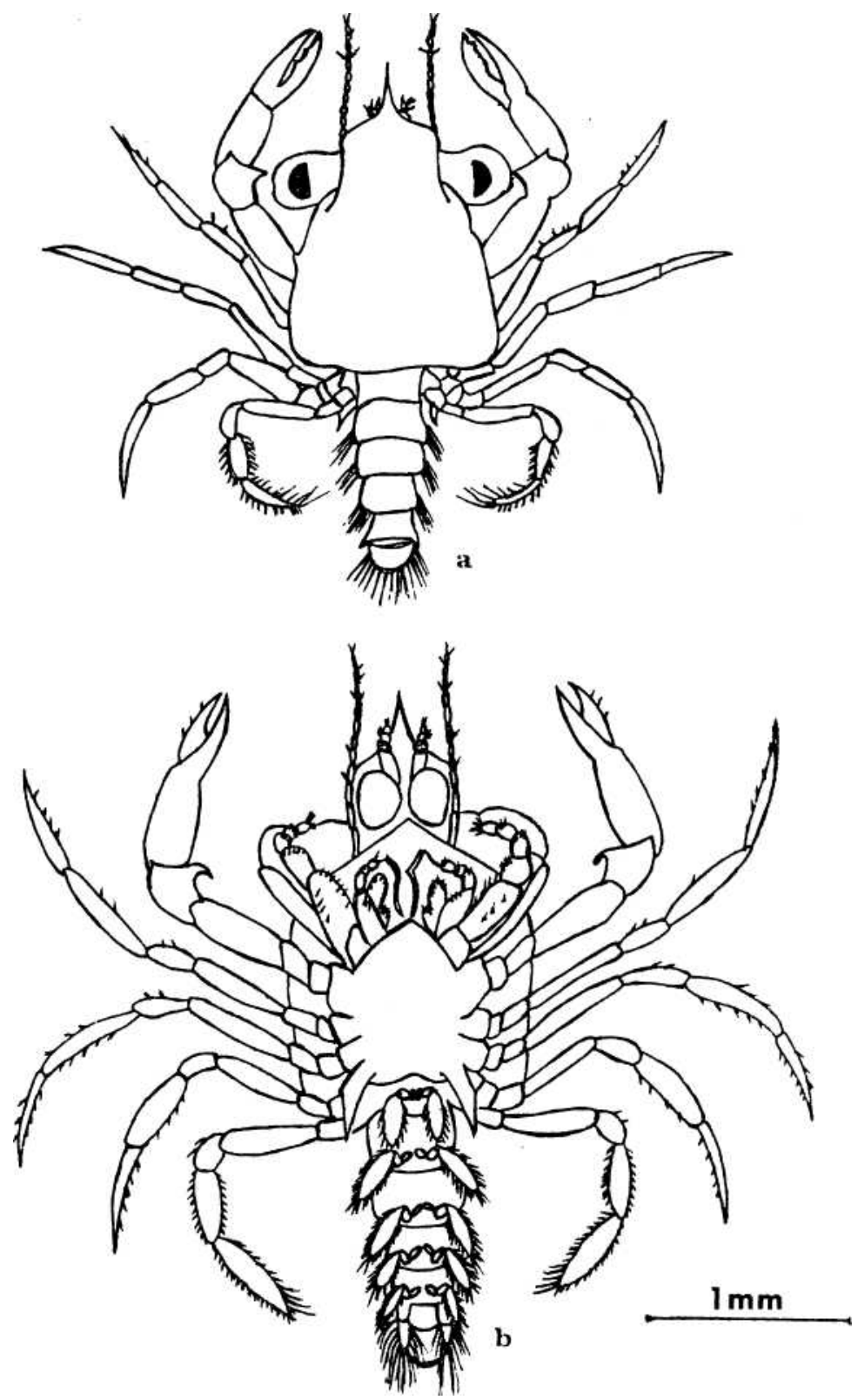

Figure 9. Megalopa of Portunus pelagicus : a, dorsal view; b, ventral view. 


\section{LARVAL DEVELOPMENT OF THE INDONESIAN BLUE CRAB}

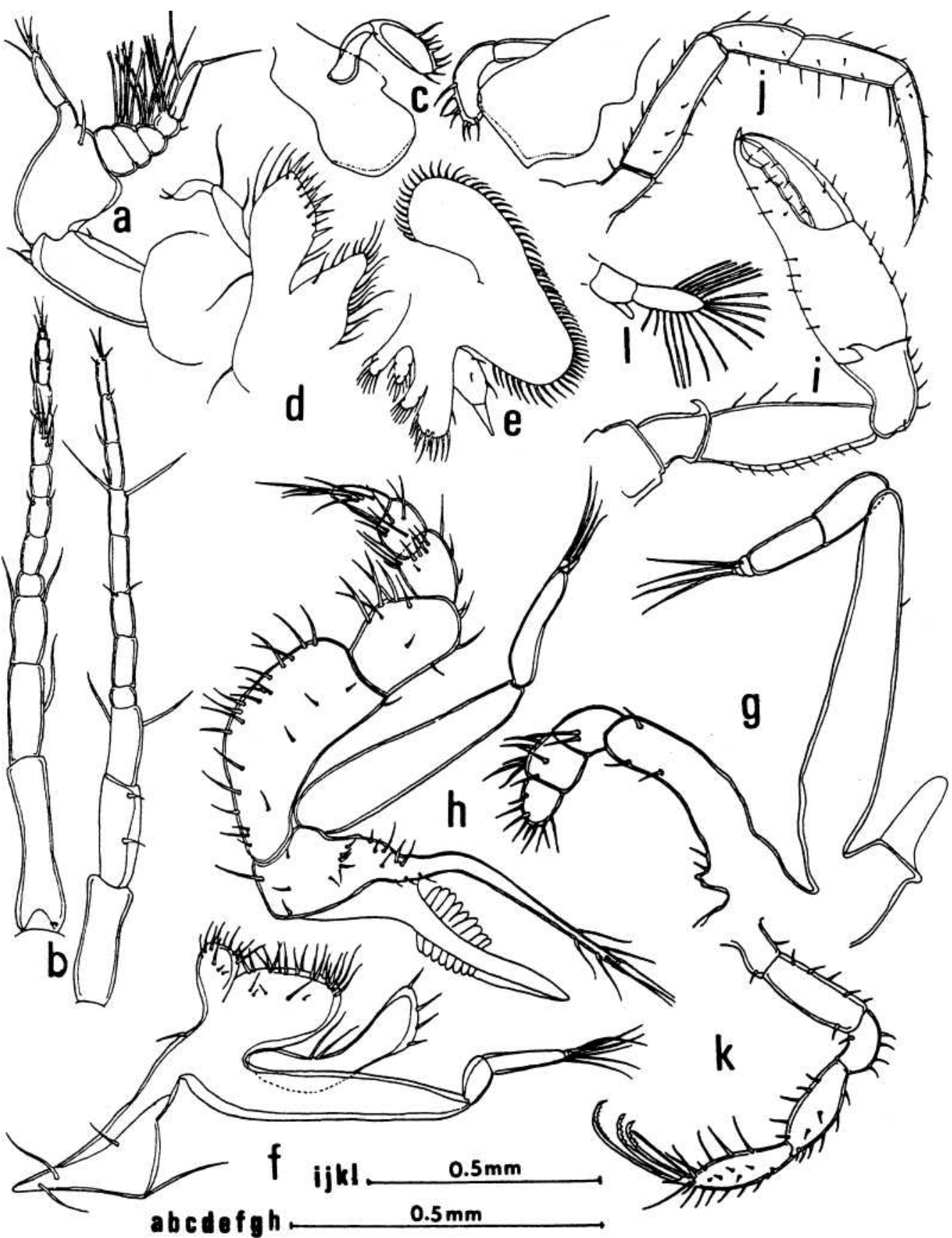

Figure 10. Portunus pelagicus megalopal appendages : a, antennule; b, antenna; c, mandible; d, maxillule; e, maxilla; f, first maxilliped; g, second maxilliped; h, third maxilliped: i, first periopod; j, second periopod; k, fifth periopod; 1, pleopod. 